\title{
Strategi Cyber Public Relations dalam Pembentukan Citra Institusi Pendidikan Tinggi Swasta
}

\author{
Gita Aprinta E.B \\ (gita@ ftik.usm.ac.id) \\ (Dosen Ilmu Komunikasi Universitas Semarang)
}

\begin{abstract}
As a strategy public relations, cyber public relations gives the new meaning for public relations practioners, especially in buliding positive image of private university (PTS). Trough cyber public relations, communcation between PTS and it public, can be bridge quickly and easy. Moreover, cyber public relations strategy provides dynamic and personal interaction, so that public posses their personal intepretation about the PTS.
\end{abstract}

Kata Kunci: Cyber Public Relations, Citra, Pendidikan Tinggi Swasta

\section{A. Pendahuluan}

Keberadaan internet menjadikan dunia komunikasi menjadi tidak terbatas. Sejak kemunculannya yang pertama kali pada tahun 1969 dan tumbuh pesat pada tahun 1990an, internet memberikan kemudahan untuk mendukung pekerjaan di berbagai industri, termasuk industri komunikasi (J. Ryan: 2010). Industri komunikasi sebagaimana didefinisikan oleh kamus ensiklopedia adalah sebuah industri yang mencakup berbagai macam kegiatan penyampaian informasi, mengacu pada kegiatan komunikasi massa secara menyeluruh. Dengan demikian melibatkan televisi, radio, surat kabar, iklan, public relations, film, penerbitan, dan industri informasi lainnya.

Sebagaimana industri lain yang berkembang sejalan dengan perkembangan teknologi komunikasi, demikan pula yang terjadi dalam industri komunikasi. Berbagai inovasi yang melibatkan internet, industri komunikasi mampu untuk menjembatani kendala komunikasi, yaitu mudah, tanpa jarak, dan gampang untuk dikonsumsi. Salah satunya adalah kegiatan Public Relations. Jika sebelumnya kegiatan Public Relations mengandalkan pusaran informasi pada media-media konvensional seperti televisi dan surat kabar, maka ditengah gempuran inovasi internet yang terus berkembang pesat dan bervariasi, kegiatan Public Relations beralih kepada jalur digital atau awam disebut sebagai Cyber Public Relations. Cyber Public Relations umum dilihat sebagai sebuah bentuk pengoperasian fungsi di dunia maya dalam praktik kerja public relations (Doherty, 1995:4).

Cyber public relations menjadi sebuah kegiatan populer yang banyak digunakan oleh perusahaan maupun organisasi dalam melakukan engagement dengan publiknya Selain menjadi jalan keluar bagi kendala komunikasi, yaitu jarak dan waktu, cyber public relations memberikan keuntungan dibandingkan kegiatan public relations dengan menggunakan media konvensional antara lain, dapat membangun hubungan yang kuat antara perusahaan atau organisasi dengan publiknya karena komunikasi yang dilakukan merupakan komunikasi dua arah, sehingga interaksi di antara keduanya menjadi lebih personal. Hal tersebut tidak bisa dilakukan langsung oleh media seperti televisi dan surat kabar. Keuntungan lainnya lagi adalah 
hemat. Dalam cyber public relations, biaya internet jauh lebih murah dibandingkan dengan biaya yang digunakan untuk pembuatan iklan baik di surat kabar ataupun televisi. (Julius Onggo,2004 : 6) Perbandingan biaya internet dan iklan dijelaskan dalam tabel berikut ini:

\begin{tabular}{|c|c|c|c|}
\hline \multicolumn{4}{|c|}{$\begin{array}{l}\text { A.1 Tabel Perbandingan Biaya } \\
\text { Internet dan Iklan }\end{array}$} \\
\hline $\begin{array}{l}\mathbf{N} \\
\mathbf{0}\end{array}$ & $\begin{array}{c}\text { Biaya } \\
\text { Internet }\end{array}$ & $\begin{array}{c}\text { Biaya } \\
\text { Iklan } \\
\text { Televisi } \\
\text { Nasiona } \\
\text { l }\end{array}$ & $\begin{array}{c}\text { Biaya } \\
\text { Iklan } \\
\text { Surat } \\
\text { Kabar } \\
\text { Nasional }\end{array}$ \\
\hline 1 & $\begin{array}{l}\text { Rp. } \\
600.000 / \mathrm{bu} \\
\text { lan untuk } \\
\text { biaya } \\
\text { internet } \\
\text { kantor } \\
\text { paling } \\
\text { murah } \\
\text { dengan } \\
\text { kecepatan } \\
\text { 1 Mbps }\end{array}$ & $\begin{array}{l}\text { Rp. } \\
30.000 .0 \\
00 \text { / } 30 \\
\text { detik } \\
\text { untuk } \\
\text { masa } \\
\text { tayang } \\
\text { prime } \\
\text { time }\end{array}$ & $\begin{array}{l}\text { Rp. } \\
226.000 .0 \\
00 \text { untuk } \\
\text { iklan } \\
\text { banner } \\
\text { halaman } \\
\text { warna } \\
\text { dengan } \\
\text { ukuran } 7 \\
\text { x } 50 \mathrm{mmk}\end{array}$ \\
\hline 2 & $\begin{array}{l}\text { Rp. } \\
15.000 .000 \\
\text { / bulan } \\
\text { untuk } \\
\text { biaya } \\
\text { internet } \\
\text { kantor } \\
\text { paling } \\
\text { mahal } \\
\text { dengan } \\
\text { kecepatan } \\
50 \text { Mbps }\end{array}$ & $\begin{array}{l}\text { Rp. } \\
2.000 .00 \\
\text { 0/ } \quad 30 \\
\text { detik } \\
\text { untuk } \\
\text { masa } \\
\text { tayang } \\
\text { dini hari }\end{array}$ & $\begin{array}{l}\text { Rp. } \\
164.500 \text { / } \\
\text { mmk } \\
\text { untuk } \\
\text { advetorial } \\
\text { dan } \\
\text { korporator } \\
\text { ial warna }\end{array}$ \\
\hline
\end{tabular}

Sumber: hasil penelusuran penulis dari berbagai sumber

Ditambah dengan berbagai feature yang diberikan oleh internet, maka kegiatan cyber public relations praktis menjadi sebuah pilihan bagi perusahaan atau organisasi untuk mengembangkan image dan menjaga reputasi di mata publiknya, karena pada dasarnya salah satu tujuan dari kegiatan public relations sebuah perusahaan adalah untuk membentuk citra positif perusahaan di mata publik secara keseluruhan.

Citra positif dibutuhkan oleh setiap perusahaan atau organisasi tidak terkecuali sebuah institusi pendidikan tinggi yang dalam hal ini adalah perguruan tinggi swasta. Perguruan tinggi swasta adalah satuan penyelenggara pendidikan tinggi yang pengelolaan dan regulasinya dilakukan oleh swasta. Dengan adanya undangundang yang disahkan pada tanggal 13 Juli 2013 mengenai otonomi perguruan tinggi negeri yang ditetapkan di seluruh Indonesia memberikan dampak tersendiri bagi keberlangsungan perguruan tinggi swasta. Persaingan yang ada tidak sekedar terbatas pada sesama perguruan tinggi swasta melainkan juga perguruan tinggi negeri. Jika pengelolaan organsisasi dan penerimaan mahasiwsa baru menjadi otonomi masing-masing perguruan tinggi negeri maka bukan tidak mungkin perguruan tinggi negeri berlomba-lomba untuk membuka program-program baru untuk menarik minat calon mahasiswa baru.

Citra PTS dapat dilihat dari berbagai faktor salah satunya adalah animo calon mahasiswa dalam memilih PTS tersebut untuk kelanjutan belajarnya. Sebagaimana perusahaan jasa lainnya, maka PTS dituntut untuk dapat meningkatkan kualitas dan mengkomunikasikan kegiatan komunikasinya agar dapat membentuk citra yang positif bagi masyarakat, yang akhirnya dapat membantu untuk meningkatkan animo masyarakat terhadap PTS tersebut.

Dengan inisiatif kegiatan public relations dalam memanfaatkan teknologi komunikasi internet atau cyber public relations, diharapkan PTS 
akan mampu memaksimalkan kegiatan komunikasinya dalam membentuk citra positif institusi pendidikan tinggi swasta.

\section{B. Cyber Public Relations}

Cyber Public Relations atau E-PR adalah merupakan inisiatif public relations yang menggunakan media internet sebagai sarana publisitas (Julius Onggo, 2004:1) Dengan memanfaatkan internet, perusahaan berusaha untuk membangun sebuah one to one relations secara simultan dan bersifat interaktif dengan publik sasarannya. Kegiatan cyber public relations tersebut dapat menghasilkan apa yang disebut sebagai 3R bagi perusahaan, yaitu (Julius Onggo, 2004:6):

1. Relations, mampu berinteraksi dengan berbagai target audiens untuk membangun hubungan dan citra perusahaan

2. Reputasi, Aset yang paling penting dalam suatu bisnis. Cyber public relations merupakan suatu senin dalam membangun reputasi online secara berkesinambungan

3. Relevansi, artinya adalah mengupayakan agar kegiatan insiatif public relations secara online relevan dengan target publik korporat.

Lapman (1979) menegaskan bahwa cyber public relations merupakan sebuah upaya yang diusahakan untuk mengelola hubungan dan pesan dalam dalam sebuah imajinasi yang disebut sebagai 'teater gagasan'. Beberapa wacana mengatakan bahwa cyber public relations adalah sebuah relasi antara dunia maya dan pengalaman berkomunikasi secara online (Samsup \& Kim, 2003), atau dengan kata lain adalah komunikasi yang efektif dalam ranah maya.
Adapun penggunaan strategi komunikasi dalam cyber public relations tidak mengalami perbedaan yang signifikan, namun lebih menekankan pada pemanfaatan teknologi komunikasi yang dapat memberikan efisiensi pada pengalaman komunikasi konsumen, seperti rasa terhubung antara konsumen terhadap perusahaan tersebut. Sehingga bisa dikatakan bahwa cyber public relations merupakan salah satu strategi dari public relations yang tidak dapat diabaikan.

Sebagai sebuah strategi, cyber public relations tentunya memiliki peranan yang cukup penting dalam pembentukan citra sebuah perusahaan. Beberapa strategi cyber public relations yang bisa digunakan antara lain:
1. Publikasi online
2. Social Media
3. Komunitas online

\section{Pembentukan Citra dan Perguruan Tinggi Swasta}

Sekarang ini, banyak perusahaan yang menganggap penting untuk memelihara publik yang baik, terbukti bahwa lebih dari $50 \%$ dari seratus top eksekutif mengatakan bahwa perlu sekali untuk memberi perhatian yang cukup untuk membangun suatu citra yang menguntungkan bagi suatu perusahaan (Soleh Soemirat dan Elvinaro Ardianto, 2010:111). Oleh karenanya bisa dikatakan bahwa citra perusahaan yang positif adalah essensial, sukses yang berkelanjutan dan dalam jangka panjang (Seitel. 1992:193)

Citra didefinisikan sebagai kesan, perasaan, gambaran diri publik terhadap perusahaan; kesan yang sengaja diciptakan dari suatu obyek, orang atau 
organisasi. Dengan demikian maka citra itu sengaja perlu diciptakan agar bernilai positif. Setiap perusahaan mempunyai citra sebanak jumlah orang yang memandangnya. Berbagai citra perusahaan datang dari pelanggan perusahaan, pelanggan potensial, bankir, staf perusahaan, pesaing, distributor, pemasok, asosiasi dagang, dan gerakan pelanggan di sektor perdagangan yang mempunyai pandangan terhadap perusahaannya. (Katz, 1994:67-68). Dalam hal ini yang menjadi publik dari perguruan tinggi swasta adalah calon mahasiswa dan juga stakeholders, meliputi, masyarakat, orang tua, pemerintah, alumni, dan investor.

Citra yang ingin dibentuk oleh sebuah perguruan tinggi swasta tentunya berkaitan erat dengan mutu pelayanan dan kualitas pembelajaran yang nantinya akan berdampak pada kualitas kelulusan sehingga akan dapat menumbuhkan kepercayaan bagi masyarakat ataupun perusahaanperusahaan sebagai end user dari lulusan tersebut.

Citra terbentuk berdasarkan pengetahuan dan informasi-informasi yang diterima oleh seseorang (Soleh Soemirat dan Elvinaro Ardianto, 2011:114). Informasi-informasi yang diterima berkaitan dengan sebuah perguruan swasta baik yang dikomunikasikan secara langsung ataupun tidak langsung akan menimbulkan perilaku tertentu, dan cenderung mempengaruhi cara seseorang dalam melihat citra perguruan tinggi tersebut. Sebagaimana yang dikatakan oleh John S Nimpoeno, bahwa proses pembentukan citra terbentuk melalui pengalaman atau stimulus yang berasal dari luar diorganisasikan dan mempengaruhi respons (Soleh Soemirat dan Elvinaro Ardianto, 2010:115)

\section{C.1 Tabel Model Pembentukan Citra}

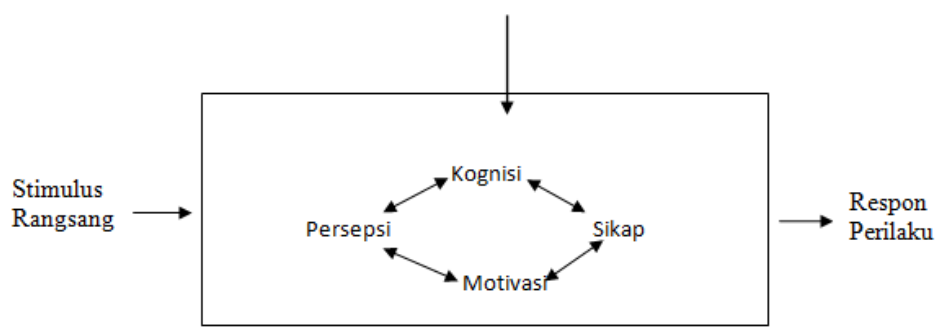

Sumber: Soleh Soemirat dan Elvinaro Ardianto. 2010;115

Empat komponen persepsi-kognisimotivasi-sikap diartikan sebagai citra individu terhadap rangsang. Ini yang disebut oleh Walter Lipman sebagai 'picture in our head". Individu akan memberikan makna terhadap rangsang berdasarkan pengalamannya mengenai perguruan tinggi swasta. Kemampuan mempersepsi itulah yang kemudian melanjutkan sebagai proses pembentukan citra.

Sebuah perguruan tinggi dikatakan baik apabila memiliki kriteria-kriteria tertentu berkaitan dengan kualitas pendidikan, kurikulum, dosen, pembiayaan, prestasi, dan faktor lainnya. Kriteria-kritera inilah yang seharusnya dapat dikomunikasikan kepada publik dengan tepat agar publik mengetahui keunggulan sebuah PTS tertentu sehingga pada akhirnya dapat membentuk citra positif terhadap PTS tersebut. Citra positif memberikan nilai tambah tertentu yang dapat meningkatkan posisi PTS di tengah masyarakat.

\section{Pembahasan}

Sebagaimana disebutkan di atas bahwa strategi cyber public relations merupakan strategi PR yang mengedepankan penggunaan media online dalam publikasinya dan untuk menjalin hubungan dengan publik sebuah perusahaan. Publik sebuah perguruan tinggi terkait erat dengan 
masyarakat, mahasiswa, orang tua, pemerintah, dan stake holders lainnya. Mahasiswa merupakan salah satu aset bagi perguruan tinggi untuk keberlangsungan hidup institusinya, terutama PTS. Dengan adanya otonomi daerah, perkembangan PTS tidak dapat dihindari, terutama di daerah-daerah perkotaan di setiap propinsi. Peran public relations di perguruan tinggi tidak hanya sekedar menjembatani hubungan antara institusi dengan mahasiswa, lembaga-lembaga terkait, pemerintah, namun juga untuk membentuk citra yang positif untuk mendapatkan perhatian dari masyarakat.

Sejalan dengan perkembangan teknologi, maka kegiatan komunikasi public relations dirasa tidak cukup jika hanya mengandalkan media massa tradisional. Animo masyarakat terhadap aktivitas digital bisa dibilang cukup tinggi, terutama dalam mengakses informasi. Hal ini dibuktikan dari survey yang dilakukan oleh Julius Onggo (2004), bahwa 95\% partisipan lebih suka mengakses artikel atau berita dari internet. Meskipun fokus utama kegiatan cyber public relations adalah pada pasar online, namun demikian akan lebih maksimal apabila digabungkan dengan kegiatan public relations secara offline.

Contohnya adalah dalam mempublikasikan informasi terkait dengan kepentingan perguruan tinggi, mulai dari informasi mengenai profil PTS, penerimaan mahasiswa baru, prestasi maupun fasilitas dan fakultas yang disediakan oleh PTS tersebut. Publikasi online bisa menjadi pilihan tepat, dari sekedar artikel di media cetak, maupun iklan. Selain website atau situs, PTS dapat memilih ezine sebagai salah satu media publikasi online-nya. Ezine atau majalah elektronik adalah versi online dari majalah yang sarat dengan artikel informasi ataupun solusi. Beberapa industri media sudah mengaplikasikan penggunaan ezine tersebut antara lain Tempo dan Detik. Ezine dapat ditampilkan dalam situs PTS ataupun dapat dikirim melalui email kepada publik PTS.

Ezine berbasis web adalah sebuah majalah yang ditampilkan dalam sebuah situs tertentu, contohnya situs PTS, dimana artikel, informasi, maupun berita mengenai PTS tersebut dapat diakses oleh siapapun secara gratis. Namun untuk dapat mengakses informasi secara optimal, maka pembaca diharuskan untuk menjadi member atau anggota dari situs tersebut. Dengan cara inilah, PTS dapat menganalisa berapa banyak orang yang menjadi publik aktif PTS tersebut. Publik aktif inilah yang kemudian dapat ditindak lanjuti dengan mengirimkan email secara rutin mengenai informasi atau kegiatan yang dilakukan oleh PTS.

Namun demikian, penggunaan ezine ini harus tetap memperhatikan content. Tampilkan konten-konten menarik agar orang ingin terus membaca dan pada akhirnya menjadi pembaca setia. Perhatikan juga panjang ezine, jika ingin dikirimkan melalui email. Sebaiknya kirimkan ezine yang berisi 2-3 artikel saja, akan tetapi frekuensi pengirimannya dibuat lebih sering, sehingga pembaca dapat terus menerima informasi terbaru mengenai PTS.

Strategi selanjutnya yang bisa digunakan adalah pemanfaatan social media. Social media adalah media yang digunakan untuk interaksi sosial menggunakan aksesbilitas tinggi yang didefinisikan oleh Andreas Kaplan dan Michael Haenlin (2010) sebagai sebuah kelompok aplikasi berbasis internet, dibandung di atas fondasi teknologi web 2.0 yang memungkinkan adanya kreasi dan pertukaran konten di antara 
pengguna. Beberapa social media yang dapat dimanfaatkan secara optimal adalah Facebook Fanpage, Twitter, dan Google +. Seperti tersebut di atas, bahwa ciri dari social media adalah pertukaran konten di antara pengguna, sehingga sangat dimungkinkan untuk terciptanya interaksi yang dinamis diantara pengguna. Maka pemanfaatan social media ini menjadi salah satu cara tepat untuk berkomunikasi secara langsung sekaligus mendapatkan social echo dari publik. PTS dapat menyebarkan informasi bahkan promosi singkat melalui akun social media yang dimiliki.

Dalam Facebook Fanpage, kegiatan komunikasi dapat dilakukan dengan menampiklan konten konten menarik seperti, video promosi, poster, maupun artikel-artikel terkait PTS. Sementara melalui twitter, dengan pembatasan karakter 140 kata dan penggunaan konsep follower, PTS dapat memanfaatkannya untuk menyampaikan informasi perihal prestasi PTS, rencana kegiatan, sekaligus digunakan sebagai media interaksi atau tanya jawab dengan para followernya.

Selanjutnya, PTS juga bisa memanfaatkan pembentukan Komunitas online untuk membentuk pencitraan positif. Komunitas online merupakan tempat yang ideal untuk membangun brand image PTS. Komunitas online terbentuk karena adanya kesamaan minat dari orang-orang yang beraktivitas di dunia maya. Komunitas online ini digunkan untuk mendiskusikan mengenai hal-hal terkait dengan PTS. Disini juga, pelaku public relations PTS dapat mengidentifikasikan pesaing dan maupun trend baru yang muncul berkaitan dengan institusi pendidikan tinggi. Orang memilih untuk mengelompokkan diri sesuai dengan apa yang diinginkan, sehingga dengan demikian melalui komunitas online ini akan terbentuk sebuah hubungan yang disebut oleh John Naisbitt (2010) sebagai hubungan yang bersifat 'high touch'.

Strategi cyber public relations, tidak terbatas pada kegiatan-kegiatan di atas, namun masih banyak lagi yang bisa digunakan untuk membantu pembentukan citra institusi pendidikan tinggi swasta. Namun hal tersebut, sekali lagi tergantung pada karakter PTS dan publiknya, sehingga sebelum menentukan strategi cyber public relations apa yang tepat untuk digunakan, maka hal paling mendasar yang harus dilakukan adalah melakukan riset pasar terlebih dahulu.

Dalam kegiatan cyber public relations, seorang pelaku public relations perlu untuk mempertimbangkan bagaimana merancang pengalaman yang memberikan perasaan baik, berbagi emosi, perasaan terhubung yang sejalan dengan pengembangan dan penyesuaian kegiatan public relations. Komunikasi melalui elektronik merupakan kunci utama dalam kegiatan cyber public relations yang memainkan peran untuk membuat spektakular sebuah realitas. Realitas mengenai PTS dapat dikelola dengan cyber public relations yang tepat untuk memunculkan citra positif bagi publik PTS tersebut.

\section{E. Penutup}

Konsep dari cyber public relations adalah sentuhan kedinamisan dalam berkomunikasi dengan menggunakan media online yang memungkinkan praktisi public relations untuk merancang pengalaman dengan publiknya secara lebih personal dan interaktif, sehingga dengan demikian akan memunculkan intepretif individu dari publik yang terlibat. Beberapa kelebihan dari cyber public relations 
adalah, kemudahan untuk mendesain dan mengirimkan pesan, jauh lebih menantang untuk dapat membina hubungan dengan orang-orang yang terkoneksi dengan teknologi, sekaligur mengintensifkan dan mempercepat pencarian makna (Naisbitt J., Naisbitt, N. \& Philips, 2001, p.9). Pencarian makna secara personal inilah yang kemudian akan membantu publik untuk dapat mempersepsikan citra positif institusi pendidinkan swasta.

\section{F. Daftar Rujukan}

Bob Julius Onggo. (2004). Cyber Public Relations. Jakarta: Elex Media Komputindo.

Doherty, M.E. (1995). Marshall McLuhan meets William Gibson in "Cyberspace". CMC Magazine. (2), 9, September 1, 1995. Retrieved 23 February, 2005.
Kaplan, Andreas M.; Michael Haenlein. Users of the world, unite! The challenges and opportunities of Social Media. Business Horizon, 2010

Katx, Bernard. 1994. Komunikasi Bisnis Praktis. Penerjemah: Soeharsono. Pustaka: Benaman Presindo

Naisbitt, J., Naisbitt, N. \& Philips, D. (2001) High Tech* High Touch. London: Nicholas Brealey Ltd

Seitel, Fraser P. 1992. The Practice of Public Relations. Columbus, Ohio: Charles E. Merril Publishing Company. Samsup, J. \& Yungwook, K. (2003). The Effect of Web Characteristics on Relationship Building. Journal of Public Relations Research, 15 (3), 199223

Sholeh Soemirat dan Elvinaro Ardianto. 2010. Dasar-dasar Public Relations. Bandung; PT. Remaja Rosdakarya 